\title{
DISTRIBUTION OF THE TRADITIONAL AGRICULTURAL LANDSCAPE TYPES REFLECTING GEOLOGICAL SUBSTRATE AND SLOPE PROCESSES IN THE KYSUCE REGION
}

\author{
MÁRIA BARANČOKOVÁ, PETER BARANČOK
}

Institute of Landscape Ecology, Slovak Academy of Sciences, Štefánikova 3, P.O.Box 254, 81499 Bratislava, Slovak Republic; e-mail: maria.barancokova@savba.sk, peter.barancok@savba.sk

\begin{abstract}
Barančoková M., Barančok P.: Distribution of the traditional agricultural landscape types reflecting geological substrate and slope processes in the Kysuce region. Ekológia (Bratislava), Vol. 34, No. 4, p. 339-355, 2015.

Traditional agricultural landscapes (TAL) are landscapes in which primarily traditional sustainable agricultural practices are currently carried out and where biological diversity is conserved thereby. The objective of this paper is to evaluate the extension of traditional landscape structures and their relationship to geological substrate and slope processes (landslides). The evaluation was concentrated on two types of TAL (extended to Kysuce region): TAL with dispersed settlements (subtype 1a and b) and TAL of arable-land, grasslands and pastures (subtype $4 \mathrm{a}$ and b). Localities with typical dispersed settlements of subtype la mostly occur on Zlín formation and cover 707.9 ha. On the deluvial formation, this type extends to 531.8 ha and on the Solán formation, to 403.6 ha. The active landslides are mostly represented in the TAL of subtype $4 \mathrm{a}$ (cadastral areas of Čadca and Oščadnica villages), of subtype $4 \mathrm{~b}$ (cadastral areas of Riečnica and Svrčinovec villages) and of subtype la (cadastral area of Svrčinovec village). The largest representation of potential landslides is on the subtype $4 \mathrm{a}$, subtype la and subtype $4 \mathrm{~b}$.
\end{abstract}

Key words: traditional agricultural landscape, landslides, slope processes, geological substrate.

\section{Introduction}

The Kysuce region is located in the south part of Slovakia and from the orographic view it covers a portion of the Slovak-Moravian Carpathians, Western Beskids and Central Beskids. In the west, it is limited by the state borders with the Czech Republic stretched along the ridge of Javorníky Mts and Turzovská vrchovina Mts. In the northwest, the region's borders pass alongside the Moravsko-sliezske Beskydy Mts and Jablunkovské medzihorie Mts. In the northeast, the Kysuce region neighbours with Poland, while the borders pass along the ridge of the Kysucké Beskydy Mts. In the east, the borders of the region reach the eastern edge of Kysucká vrchovina Mts, which together with the Kysucká brána gate, also form the southern border of its territory. The southwestern part of Kysuce region is represented by Javorníky Mts (Mazúr, Lukniš, 1986).

Traditional agricultural landscape (TAL) structures represent ecosystems that consist of a mosaic of small-scale arable fields and permanent agricultural cultivation such as grasslands, 
vineyards and high-trunk orchards. TALs are described as landscapes where traditional sustainable agricultural practices are currently carried out and biological diversity in conserved (Harrop, 2007). These areas represent regions with specific combinations of natural and cultural diversity with high visual quality and public preferences (Tempesta, 2010).

They are significant as unique islands of species-rich plant and animal communities. History has recorded many successive and even devastating landscape changes, which have barely left any TAL relics today (Marini et al., 2011). The changes are seen as a menace, as a negative evolution because they cause a loss of diversity, coherence and identity, which were characteristic for the traditional cultural landscapes that are rapidly vanishing (Antrop, 2005).Traditional land-use systems in Europe have mainly persisted in upland and remote areas where physical constraints have prevented agricultural modernisation (Plieninger et al., 2006).

The Kysuce region is a significant historical region of Slovakia known for its specific natural characteristics and values as well as for its characteristic type of settlements that resulted from its historical colonisation. The region has a rich history, which has been ultimately reflected in the character of its population, culture, architecture, folklore and tradition (Tóthová et al., 1996).

Great changes in the agricultural land structure and agricultural land property took place in Slovakia and other European post-socialist countries (Olah et al., 2009; Gerard et al., 2010). During the period of collectivisation (1950s-1970s) a substantial part of TAL located at positions of lower altitudes was destroyed by intentional land consolidation and by plowing away the field margins. By way of this process, large tracts of arable land were created, which were gradually converted into large-scale recultivated highly productive grasslands. Individual elements of TAL were preserved only in the vicinity of the settlements on the steeper slopes with difficult access for agricultural machinery or on the relatively small areas that were less suitable for large-scale land cultivation. Originally, the landscape was covered continuously by forest. The landscape has changed due to human activities (shepherds, farmers) of harvesting or burning the forest and replacing it with fields and meadows.

Central and Eastern European countries followed the example of Soviet Union. However, agricultural land was not completely collectivised in Slovakia as it was in former Soviet Union countries (Swinnen, 1999; Palang, 2010). The regions, where TAL is still preserved, generate specific and unique landscape image, especially in sloping areas where terraced and enclosed landscapes were created over a long period (Agnolleti, 2011; Cullotta, Barberra, 2011).

All landscape types maintain the history of our human society and create an important basic of the cultural and natural heritage of the territory. This appears as a mosaic of small-scale arable fields and permanent agricultural cultivations depending on the specific regional agrarian culture. Based on the presence of specific land use elements, the following classes of traditional agrarian landscape have been distinguished: TAL with dispersed settlements, TAL of vineyards, TAL of arable land, grasslands and orchards and TAL of arable land and grasslands (Špulerová et al., 2014a, b).

\section{Material and methods}

The input parameters for this evaluation were TAL types, geological characteristics of area and landslides of area. Using the synthesis of TAL types with these individual parameters, the evaluation of their relation to its extension was determined. Final maps were created using the GIS ArcGIs 10.0 software programme. 


\section{Study area}

The Kysuce region is localised in the Northwest Slovakia on the border with Poland and Czech Republic (Fig. 1). The landscape of the Kysuce region is relatively homogeneous. Except for the southern border through which a narrow strip of limestone cliffs passes, the whole area is dominated by flysch. The monitored territory of Kysuce region was determined on the basis of natural-residential types of regions of Slovakia (Miklós, 2002).

Geologic, geomorphologic and climatic diversity as well as variability of culture and political and economic systems are all factors that have affected the Kysuce region and contributed to the diversity of this agricultural landscape.

The most widespread unit is Kysucká vrchovina Mts. Its diversity and variability of relief is the result of selected erosion-denudation processes that occurred during the Quaternary in many different forms depending on the structure and lithological characteristics of the rocks. It is created from two different structural units reflected in the morphology of the terrain. The southern part belongs to the Klippen belt and its relief has features of steep slopes. The northern part consists of flysch formation, which is more monotonous and has a more massive character.

Turzovská vrchovina Mts does not have a central ridge and is divided into separate ridges by flow valleys. Elevation ranges from $600-900 \mathrm{~m}$. It belongs to disconnected mountains. Surface plasticity is conditioned to tectonic movements in Neogene and Quaternary and was created by erosion-denudation processes depending on the resistance of rocks. On the position of the middle, resistant sandstone complexes bind slightly modelled ridges.

Javorníky Mts. represent the mountain range with a thrust-folded structure. There are heterogeneous as most flysch mountains. There are two parts: high Javorníky - massive upland relief in the north part and low Javorníky - broken highland foothills in the south part. Both parts vary in amplitude relief. The important elements of relief are planar and block slides.

There are three basic geological tectonic units involved in the geological structure of the territory (Potfaj et al., 2002; 2003a), that is, in the direction from northwest to southeast, there are the Silesian Nappe, the Magura Nappe and Klippen belt. The Silesian Nappe occupies the smallest part of the territory and occurs only marginally in its northwestern part. It consists of formation of the Godula sequence (the submenilite and Krosno Formations). The Magura Nappe represents a predominant part of the territory and consists of the following partial units: Rača, Bystrica and Oravská Magura. The Rača

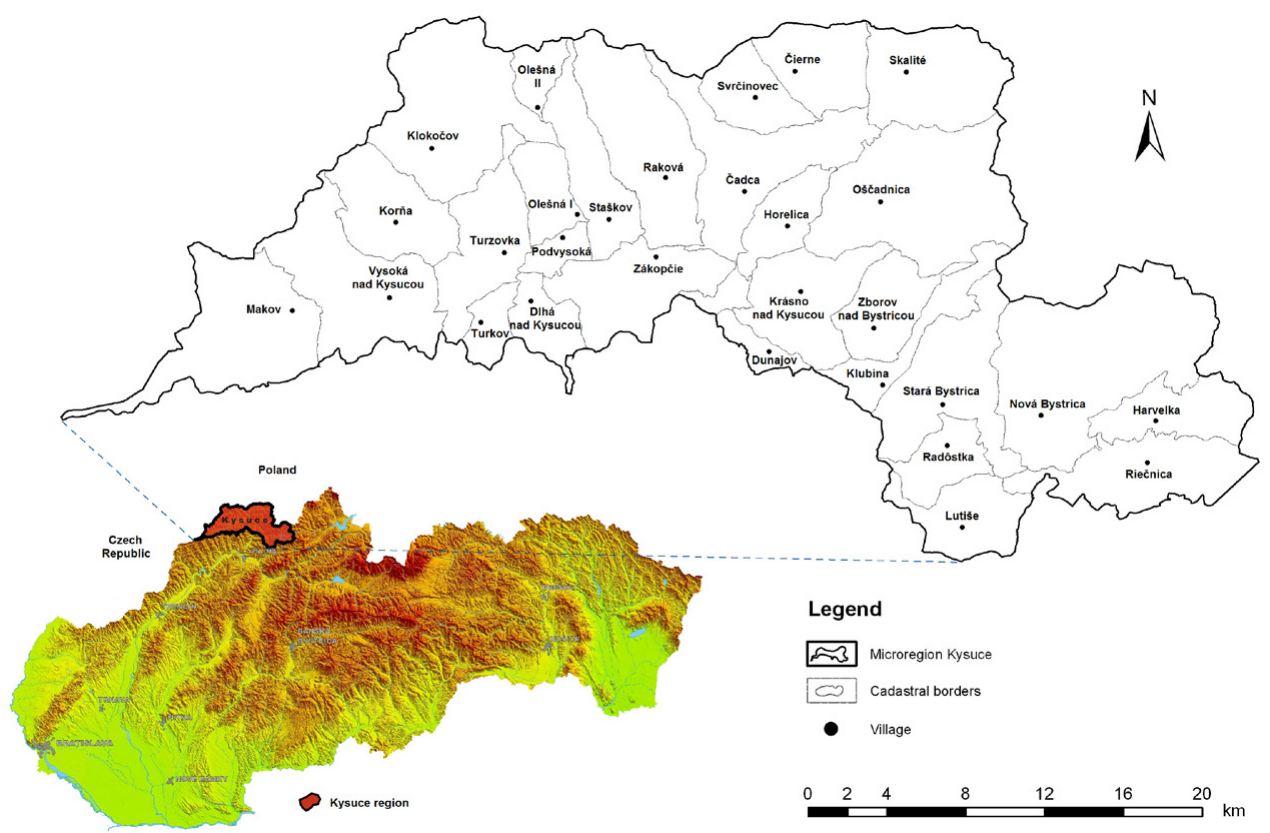

Fig. 1. Localisation of study site. 
unit extends from the Polish-Slovak borders to the south of the Dunajov village and the Klubina village along the Bystrica valley up to the Vychylovka village. The Zlín formation is the most widespread formation, in which thin strips of the Beloveža and the Solán formations are clinched. The Soláň formation represents a predominantly sandstone complex. It extends in a narrow strip from the Čierňanka river in the Svrčinovec village and continues northeast to the Skalité village. The Beloveža formation consists of thin-layered flysch deposit of claystones, which are alternated in the rate of 5:1 up to 10:1 with beds of grained siliceous-calcareous sandstones (Žabková et al., 2003). They were earmarked in the territory of Oščadnica site. There are more significant zones earmarked within the Zlín formation: the north part with the dominant representation of the Vsetín member and the south part, which is characterised by the presence of the Kýčera Member. The Vsetín member is characterised by the predominance of claystones over sandstones in the rate of 2:1 up to 10:1 and the Kýčera member is characterised by the distinct share and in some places, with predominance of graywacky sandstones in the rate of 2:1 up to 3:1. The Bystrica unit covers the area between the Rača unit and the Klippen belt. Between the villages of Lutiše and Stará Bystrica its width reaches up to $1.3 \mathrm{~km}$. It is formed of claystones with sandstone positions. The Formation is relatively less resistant to the tectonic depressions and erosion. It extends in long narrow depressions. The Oravská-Magura Unit covers an area along the northern border of the Klippen belt and is represented by the Malcov and Racibor formations comprised fine-grained sandstones and calcareous claystones (Potfaj et al., 2003b).

The diverse geomorphological value of individual formations of flysch development played an important role during the formation of the flysch relief. The Pliocene damage of larger structures was followed by the intensive application of selective erosion in dependence on variably resistant geological and tectonic structure of flysch. Alternating zones of the less resistant flysch in the predominant claystone development with more consistent zones of flysch in sandstone development were due to the long-lasting exogenous processes of periglacial modelling, river erosion and denudation during the Quaternary modelled into the long-layered ridges. Favourable conditions for the development of creeping slope deformations are concentrated in the areas where sandstone-dominated flysch is lying on claystone-dominated flysch.

The largest area of the region is composed of deluvial sediments, which are represented in the locality with a wide range of lithological types from clays, loams to debris with different content of fragments. Increased exponents occur mostly at the foothill of slopes, at the borders of valleys and in saddles. The cyclical nature of the Quaternary climate in connection with variably intense neotectonic dynamics of area had caused the alternation between vertical and lateral erosion, that is, the accumulation of fluvial sediments in stages, thereby predetermining the formation of the system of river terraces. They had been preserved, especially on the adjacent slopes of Kysuca and Bystrica valleys and in the valleys of their larger tributaries such as Olešanka, Raková, Rieka, Čierňanka, Milošovský potok, Oščadnica, Vychylovka, Radôstka and others.

Climatic classification according to the Landscape Atlas (Lapin et al., 2002) classifies the Kysuce region into two areas. One-half of the territory belongs to the temperate climate (slightly warm, very humid, mountainous area) with the highest temperature in July reaching approximately $16^{\circ} \mathrm{C}$ and with the average number of summer days less than 50 . The secondhalf of the territory belongs to the cold climate with a slightly cold area and an average temperature in July less than $16^{\circ} \mathrm{C}$.

The climate variability in terms of air temperatures manifests its tendency in the increase of average annual air temperatures, especially in the last decades. The most significant increase in air temperature was during the period from January till April and then in November (Table 1 - processed according to Slovak Hydrometeorological Institute - SHI). Extremes in the summer air temperatures were more significant in the early 90 s of the $20^{\text {th }}$ century, especially between 1992 and 1994, when compared with an average of 40 summer days in the region, 52-58 summer days occurred in Čadca town, of which $20-28$ days had temperatures above $30^{\circ} \mathrm{C}$ (Soták et al., 2002). In this century, the greatest number of summer days occurred during the year 2007 (54), the year 2008 (46) and the year 2006 (43).

$\mathrm{T}$ a b l e 1 . Average monthly and annual air temperature $\left({ }^{\circ} \mathrm{C}\right)$ and precipitation $(\mathrm{mm})$ in Čadca town.

\begin{tabular}{|c|c|c|c|c|c|c|c|c|c|c|c|c|c|}
\hline Year/month & I. & II. & III. & IV. & V. & VI. & VII. & VIII. & IX. & $\mathrm{X}$. & XI. & XII. & Year \\
\hline \multicolumn{14}{|c|}{ Temperature $\left[{ }^{\circ} \mathrm{C}\right]$} \\
\hline $1951-1980$ & -3.7 & -2.3 & 1.2 & 6.3 & 11.4 & 15.0 & 16.2 & 15.5 & 11.9 & 7.5 & 3.0 & -1.4 & 6.7 \\
\hline $1981-2000$ & -2.2 & -1.3 & 2.0 & 7.2 & 12.4 & 15.8 & 17.3 & 16.8 & 12.2 & 7.1 & 2.7 & -1.8 & 7.3 \\
\hline 2001-2014 & -2.6 & -1.6 & 1.9 & 7.7 & 12.7 & 15.9 & 17.9 & 16.8 & 12.0 & 7.8 & 4.2 & -1.5 & 7.6 \\
\hline \multicolumn{14}{|c|}{ Precipitation [mm] } \\
\hline $1951-1980$ & 56 & 53 & 50 & 66 & 88 & 121 & 126 & 100 & 67 & 58 & 66 & 65 & 915 \\
\hline $1981-2000$ & 60 & 50 & 60 & 67 & 87 & 111 & 107 & 87 & 79 & 52 & 70 & 70 & 902 \\
\hline $2001-2014$ & 66 & 49 & 55 & 48 & 99 & 99 & 126 & 79 & 75 & 57 & 58 & 54 & 865 \\
\hline
\end{tabular}


In terms of precipitation, Kysuce region belongs to humid climate zone. The average annual precipitation in the northern areas of the Kysuca valley reaches $950-1050 \mathrm{~mm}$. The highest average monthly precipitation occurs in June and July. In the Kysuca basin, the precipitation reaches 95-105 mm and in the Hornokysucké basin, even up to $120 \mathrm{~mm}$ (Soták et al., 2002). During the last decades, the annual precipitation and the precipitation during the summer months exhibit a decreasing trend (Table 1 - processed according to SHI).

\section{Results and discussion}

\section{Traditional agricultural landscape}

There are four types of TAL distinguished, in the terms of land use, within the nation-wide mapping of TAL: type 1) TAL with dispersed settlements, type 2) TAL of vineyards, type 3) TAL of arable land, grasslands and orchards and type 4) TAL of arable land and grasslands (Špulerová et al., 2011). Research into TAL in Kysuce focussed on mapping their distribution and contributing to improvement in the quality of life in rural areas. On the basis of field mapping, there are two types of TAL earmarked in the Kysuce territory (Barančok, Barančoková, 2012):

1. TAL with dispersed settlements (type 1):

a) Localities with a typical dispersed settlements (called 'kopanice,'lazy') (subtype 1a)

b) Localities with a specific type of settlement that is characteristic for Kysuce region (subtype 1b)

2. TAL of arable land, grasslands and pastures (type 4):

a) Localities with typical structures of arable land, grasslands and pastures and typical forms of anthropogenic relief (subtype 4a)

b) Localities of TAL with dominant woody vegetation (subtype $4 \mathrm{~b}$ )

Almost $12 \%$ of the Kysuce region can be characterised as territory with presence of TAL. Among the most represented are the typical TAL with presence of characteristic forms of anthropogenic relief (almost 10\%), including areas with typical dispersed settlements. The respective types of TAL most often occur outside the main axis of the settlements that are spread along the watercourses of the major rivers (Kysuca, lower watercourses of Čierňanka and Bystrica). The largest total representation of TAL is in the cadastres, which wholly expand or encroach into the mountain ranges. Lower presence of TAL appears in the territories with continuous forest complexes or in the lower and middle parts of the main valleys where these forms were destroyed during the period of collectivisation (Table 2).

\section{Extension of TAL reflecting geological bedrock}

The data from geological map of the territory were used for the evaluation of the geological bedrock (Haško, Polák, 1979a, b; Potfaj et al., 2002; 2003a). The study area contains 41 geological units. For the evaluation of the relation and extension of TAL on the basis of geological bedrock, it is not necessary to work with this detail and therefore, the geological units were reclassified into nine units (on the basis of the similarity of lithological and engineering-geological properties of rocks): 1 - fluvial sediments; 2 - proluvial sediments; 3 - deluvial sediments; 4 - Godula sequence (Krosno, Menilite, Submenilite and Istebna formations); 5 - Zlín Formation (Vychylovka and Beloveža formations, except for Kýčera member), characterised by the prevalence of claystones 


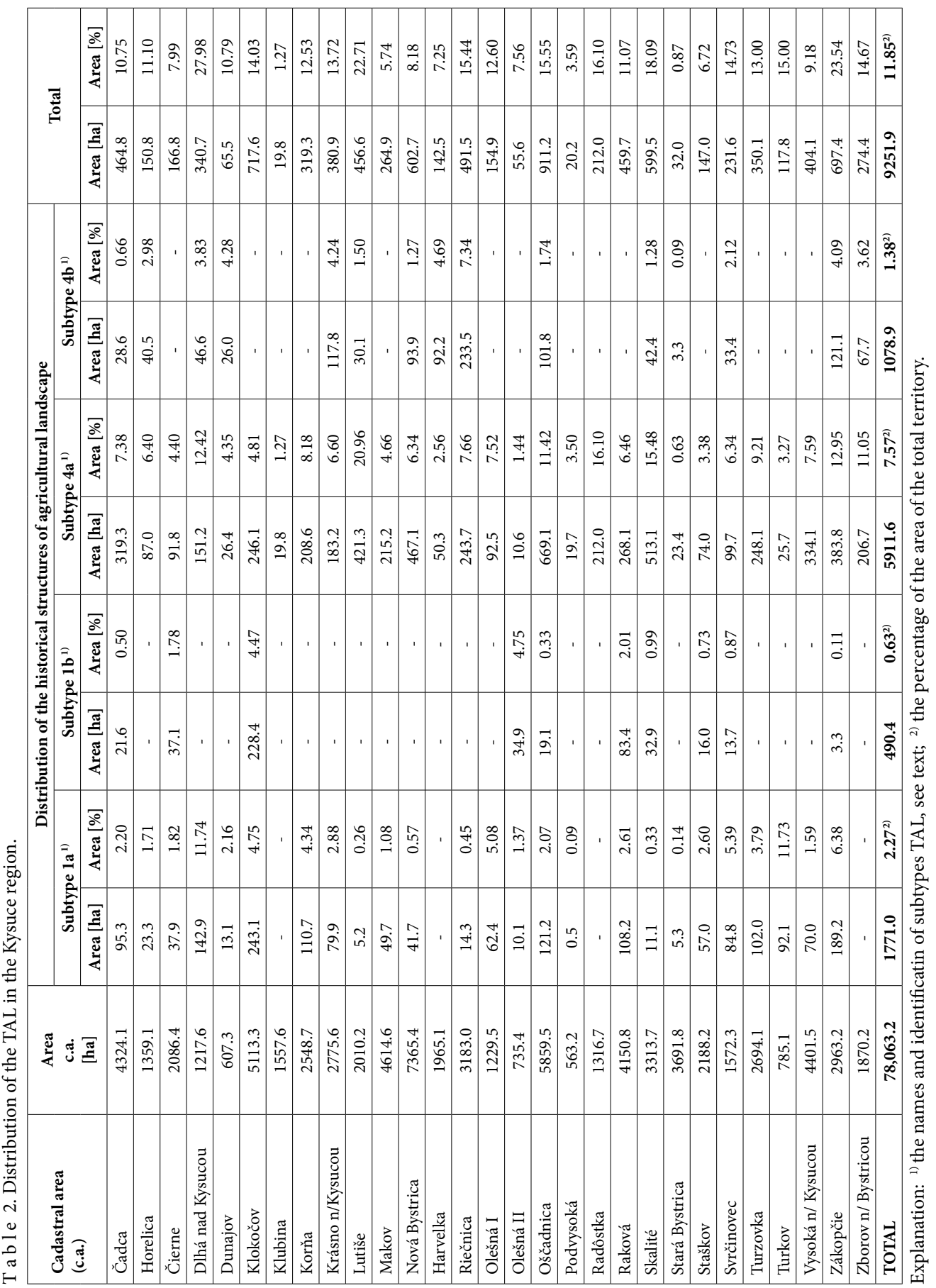


over sandstones; 6 - Soláň fomations (Kýčerska member) $\left(182.6 \mathrm{~km}^{2}\right)$, characterised by prevalence of sandstones over claystones; 7 - Bystrica unit; 8 - Oravská Magura unit; 9 - Klippen belt.

The area of the individual reclassified geological units within the study territory is evaluated in Table 3, in which the areas of the units within the total area of TAL are also stated.

The most widespread types of TAL are subtype 1a - that is, localities with typical dispersed settlements (called 'kopanice,'lazy'), that occupies an area of 17.6 out of the total $92.0 \mathrm{~km}^{2}$ and subtype $4 \mathrm{a}$ - that is, localities with typical structures of arable land, grasslands and pastures and typical forms of anthropogenic relief that occupies an area of $58.9 \mathrm{~km}^{2}$. Less widespread types of TAL are localities with a specific type of settlement that is characteristic for Kysuce region (subtype $1 \mathrm{~b}$ ), occupying an area of $4.6 \mathrm{~km}^{2}$ and localities with dominant non-forest woody vegetation (subtype 4b), occupying an area of $10.7 \mathrm{~km}^{2}$.

On the basis of the superposition of maps, the TAL are most widespread on Zlín formation (36.6\%), on deluvial sediments (28.1\%), and are less widespread on Bystrica unit (15.1\%) and on Soláň formation (13.1\%).

$\mathrm{T}$ a b l e 3. Area of geological units.

\begin{tabular}{|l|c|c|c|}
\hline Geological units & Total area $\left[\mathbf{k m}^{2}\right]$ & Area with TAL $\left[\mathbf{k m}^{2}\right]$ & Total area of TAL [\%] \\
\hline Fluvial sediments & 44.05 & 2.05 & 2.23 \\
\hline Proluvial sediments & 5.75 & 0.54 & 0.58 \\
\hline Deluvial sediments & 167.50 & 25.86 & 28.10 \\
\hline Godula sequence & 36.44 & 3.16 & 3.44 \\
\hline Zlín formation & 283.27 & 33.72 & 36.64 \\
\hline Soláň fomations & 121.11 & 12.07 & 13.13 \\
\hline Bystrica unit & 118.62 & 13.96 & 15.16 \\
\hline Oravská Magura unit & 1.40 & 0.58 & 0.63 \\
\hline Klippen belt & 0.19 & 0.05 & 0.06 \\
\hline
\end{tabular}

Localities with typical dispersed settlements of subtype la mostly occur on Zlín formation and cover 707.9 ha $(40.1 \%$ of the area of TAL). On the deluvial formation, this type extends to 531.8 ha (30.1\%) and on the Solán formation, to 403.6 ha (22.8\%). Localities with specific type of settlement that is characteristic for Kysuce region (subtype 1b) are most widespread on deluvial sediments where they cover $41.9 \%$ of the area (194.5 ha) and on Godula sequence where they cover $30.1 \%$ of the area (139.8 ha).

The Zlín formation is represented by numerous localities with typical structures of arable land, grasslands and pastures and typical forms of anthropogenic relief (subtype 4a), which occupy $2230.1 \mathrm{ha}$ (37.8\%). On deluvial sediments, the localities of subtype 4a cover an area of 1647.1 ha, which represents $27.9 \%$ of the total area of TAL and on Bystrica unit, they cover an area of 1008.1 ha (17.1\%). Localities with TAL of subtype $4 \mathrm{~b}$ have also an extensive representation on Zlín formation. They extend over an area of 367.5 ha (34.0\% of TAL). On Bystrica unit, they cover an area of 343.7 ha (31.8\%) and on deluvial formations, an area of 212.7 ha (19.7\%) (Fig. 2).

From the above-mentioned facts, it follows that the most widespread TAL on Zlín formation are those of subtypes 1a, $4 \mathrm{a}$ and $\mathrm{b}$. The dispersed settlement of subtype 1a relates mainly to the Zlín formation and less to the deluvial sediments. The specific type of settlement characteristic 


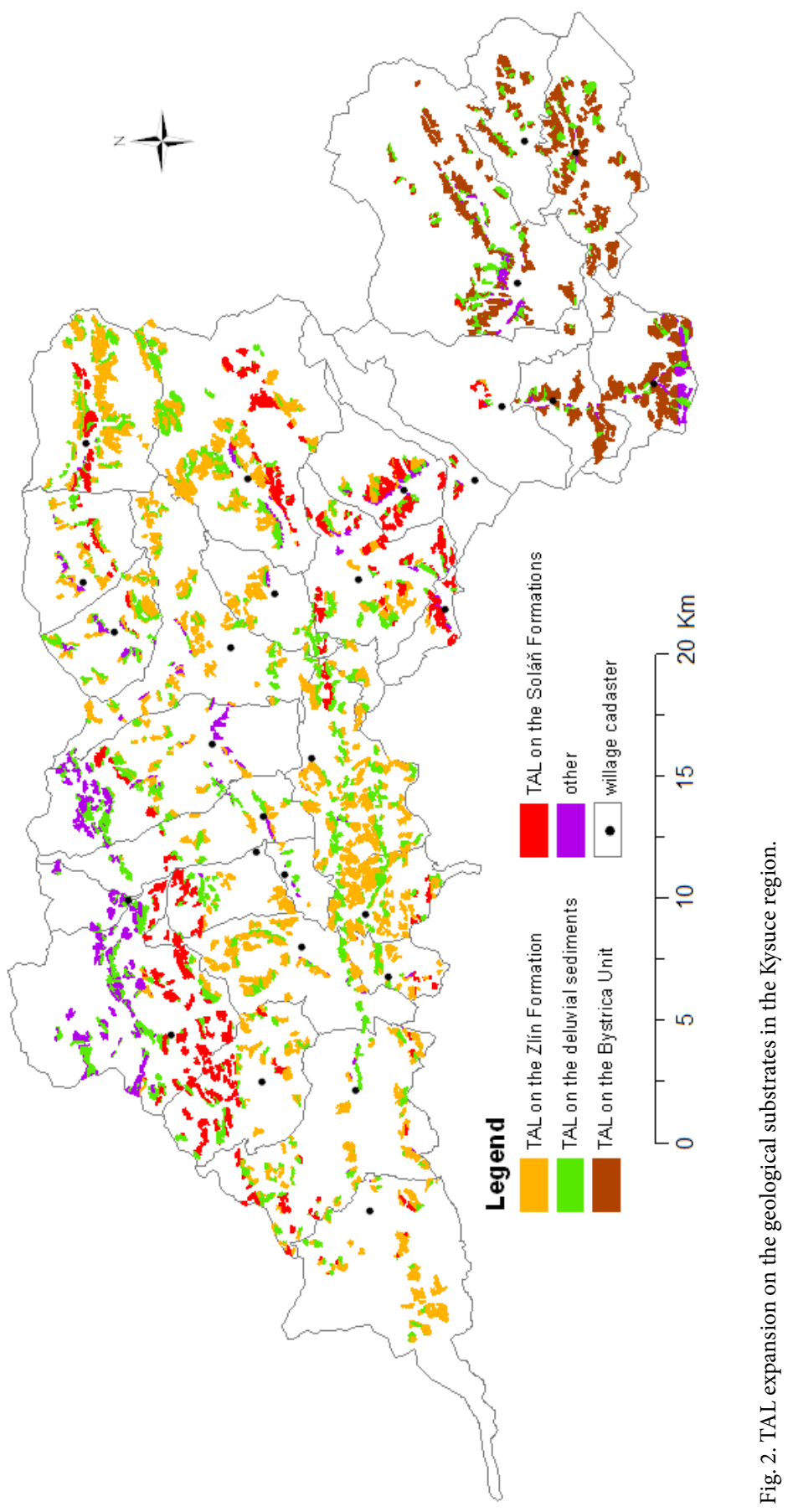


for Kysuce region (subtype 1b) is related mainly to the deluvial sediments and Godula sequence. These types of TAL extend mainly in the central and northwestern parts of the territory. The specific types of TAL of arable land, grasslands and pastures (subtypes 4a, 4b) relate mainly to Zlín formation and Bystrica unit, which are the eastern and southeastern parts of the territory.

The TAL localities that extend on Zlín formation have the largest representation in the cadastral area of Makov village where they cover $80.2 \%$ of the total area of TAL as well as in the cadastral areas of Čadca town (68.6\%), Krásno nad Kysucou village (65.7\%), Zákopčie village (64.0\%), Skalité village (56.9\%) and Oščadnica village (51.9\%). The extension of TAL on deluvial sediments ranges from 15 to 35\%, with the largest area being in the cadastral areas of Staškov village (41.7\%) and Klokočov village (38.4\%). The Solán formation has the highest dominance of TAL localities in the cadastral areas of Dunajov village (67.8\%), Zborov nad Bystricou village (47.8\%) and Korňa village (40.4\%). On the Bystrica unit, the TAL localities have the largest representation in the cadastral areas of Radôstka village (83.7\%), Riečnica village (81.5\%), Harvelka village (73.1\%), Lutiše village (68.9\%) and Nová Bystrica village (65.4\%). Fig. 3 shows the extension of individual geological units in relation to the area of TAL.

Localities with TAL of arable land, grasslands and pastures of subtypes $4 \mathrm{a}$ and $\mathrm{b}$ are the most widespread on the Zlín formation, Bystrica unit and deluvial sediments (Fig. 4). The highest representation of these types is in the cadastral areas of Makov village, Čadca village, Krásno nad Kysucou village, Zákopčie village, Skalité village, Oščadnica village as well as in the cadastral areas of Radôstka village, Riečnica village, Harvelka village, Lutiše village and Nová Bystrica village.

The TAL with dispersed settlements of subtype 1a are substantially represented on Zlín formation and deluvial sediments as well as on the Bystrica unit and dispersed settlements of subtype $1 \mathrm{~b}$ on the Godula sequence. The most widespread TAL of the aforementioned types are located not only in the cadastral areas of Klokočov village, Olešná village, Dunajov village, Korňa village, Krásno nad Kysucou village, but also in the Zborov nad Bystricou village.

\section{Extension of TAL reflecting landslides}

The data about the territory slope deformation were determined according to the publication of Šimeková et al. (2006), Žabková et al. (2003) and Starinský (2004). A large number of landslides are mainly linked to the most expanded geological unit on the Zlín formation, which covers $283.27 \mathrm{~km}^{2}$. Landslides occupy $15.23 \%$ of the total area of geological unit $\left(43.15 \mathrm{~km}^{2}\right)$. There are the most expanded potential landslides $\left(30.52 \mathrm{~km}^{2}\right)$. The second most expanded unit is deluvial sediments and landslides here represent $32.26 \%$ of the total area $\left(54.3 \mathrm{~km}^{2}\right)$ and potential landslides occupy $37.13 \mathrm{~km}^{2}$. Landslides on the Godula sequence of the Silesian unit cover about $20 \%$ of the area. Of the total area of $36.44 \mathrm{~km}^{2}$ landslides occupy $7.44 \mathrm{~km}^{2}$. Landslides in the Bystrica unit occupy almost $16 \%$ and the Solán formation $12 \%$ of the area (Table 4 ).

In the study territory, the landslides are located in the area of $148.3 \mathrm{~km}^{2}$ of the total area of $780.6 \mathrm{~km}^{2}$, thus representing $19 \%$ of the territory. Potential landslides have the largest expansion; their area is $101.2 \mathrm{~km}^{2}(12.9 \%)$. Active landslides' area is $1.8 \mathrm{~km}^{2}$, that is, $0.24 \%$ and stabilised landslides' area is $45.8 \mathrm{~km}^{2}$, that is, $5.86 \%$ (Table 5).

Intensive development of geodynamic phenomena of various types is a response to a fading neotectonic movements, varied geological structure, gradual development of relief that resulted 


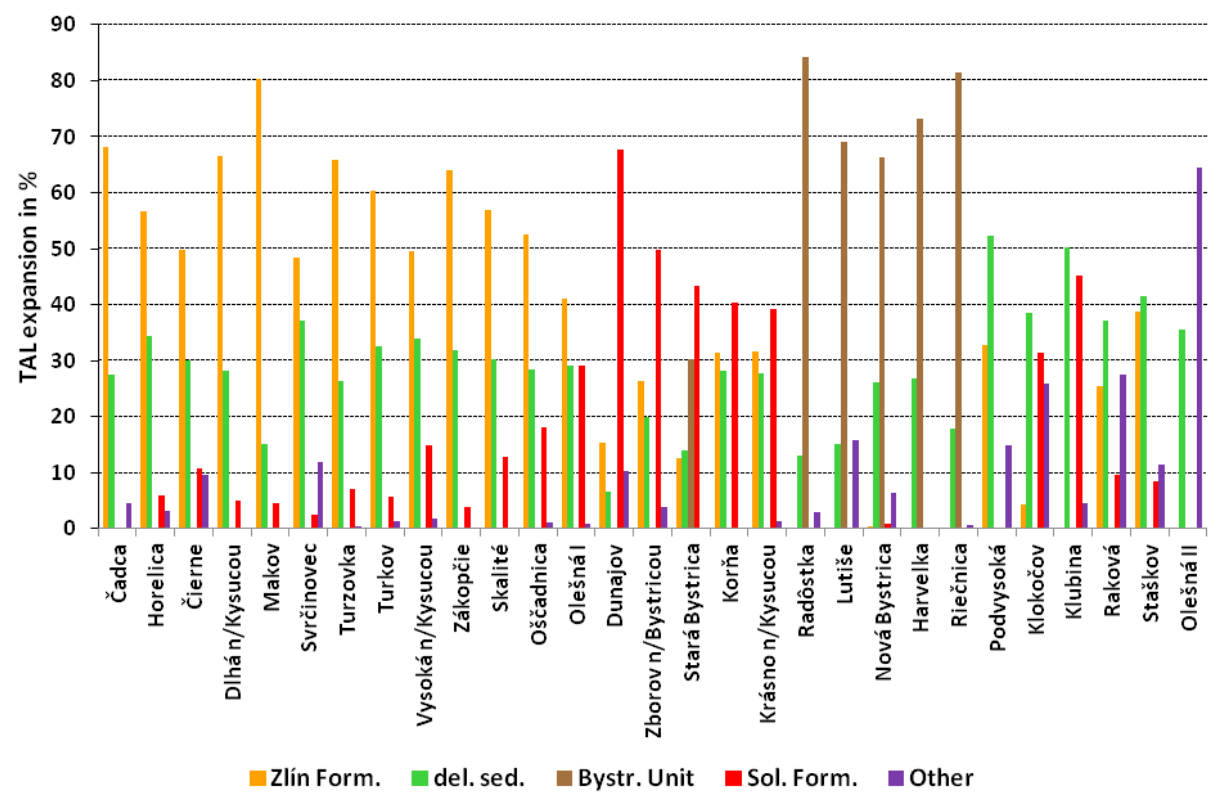

Fig. 3. Extension of selected geological units on the areas of TAL in the relevant cadastral areas.

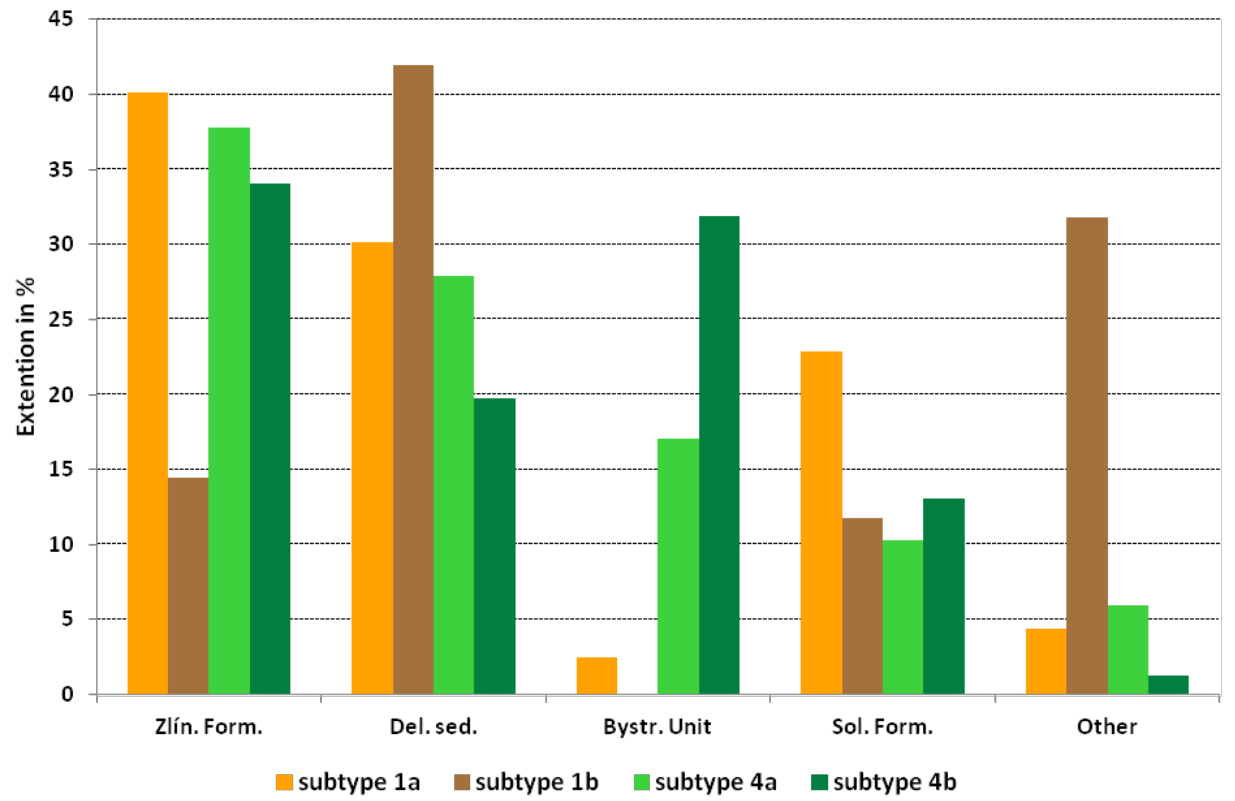

Fig. 4. The representation of geological units in the individual types of TAL. 
$\mathrm{T}$ a b l e 4. Extension of landslides in individual geological formations.

\begin{tabular}{|l|c|c|c|c|c|}
\hline \multirow{2}{*}{ Geological units } & \multirow{2}{*}{$\begin{array}{c}\text { Total area } \\
{\left[\mathbf{k m}^{2}\right]}\end{array}$} & Active & Potential & Stabilised & Total \\
\cline { 3 - 6 } & 44.05 & 0.82 & 1.24 & 0.30 & 2.36 \\
\hline Fluvial sediments & 5.75 & - & 0.12 & 0.05 & 0.17 \\
\hline Proluvial sediments & 167.50 & 0.95 & 37.13 & 15.96 & 54.04 \\
\hline Deluvial sediments & 36.44 & - & 3.63 & 3.81 & 7.44 \\
\hline Godula sequence & 283.27 & 0.49 & 30.52 & 12.14 & 43.15 \\
\hline Zlín formation & 121.11 & 0.06 & 10.78 & 4.09 & 14.93 \\
\hline Soláň formation & 118.62 & 0.03 & 13.00 & 5.92 & 18.95 \\
\hline Bystrica unit & 1.40 & - & 0.02 & 0.06 & 0.80 \\
\hline Oravská Magura unit & & &
\end{tabular}

in a ragged area but, especially to climatic and hydrogeological conditions of the area. The most frequent slope phenomenon in the territory is slope deformations because extensive part of the area creates favourable conditions for their formation. They cover approximately one-fourth of the area. Significant influence of the slope deformations on the current geomorphological character of the territory reflects the quality of the basic components of the natural environment rocks, groundwater, relief, their mutual interactions as well as their interactions with the outside environment.

Paleogene complexes of rapidly weathering flysch represent good base for the creation of massive deluvial covers. The interface between deluvium and pre-Quaternary basement that had been enhanced by the extensive solifluction processes is extremely favourable for the formation of skidding surfaces and often provides very suitable hydrological conditions for reactivation of slope movements Andor (1978). Each slope has a certain degree of activity. Decrease in its stability is caused by the action of natural factors like precipitation anomalies, weathering of rocks caused by exogenous factors, gradual burdening of slopes, uneven process of slope destruction, seismic disturbance of slopes, slope inclination and flow erosion. In addition to natural factors, important role in activation of slope movements has also human activity, especially unsuitable interferences into the slope Ondrášik, Rybář (1991).

The most frequent cause of slope deformations in flysch and flysch-similar formations is the exceeding the claystones strength, respectively, in marlstones, within the weathering zone during the slope formation and the increase in buoyancy effects of the water. The increase in buoyancy effects of water is related in a very small evaporation percentage to the long-term precipitation during autumn and spring and to snow melting, especially in the insufficiently frozen soil.

Landslides represents the most sensitive type of all slope deformations and are especially sensitive to climate change and changes of other natural conditions as well as inappropriate structural interventions and inadequate maintenance of structures that serve as drainage basins for surface water and groundwater.

In the observed territory, the TAL covers $92.5 \mathrm{~km}^{2}$ of area and landslides cover 148.3 $\mathrm{km}^{2}$ of area. Superposition of TAL and landslides determined that the TAL and landslides together cover $22.7 \mathrm{~km}^{2}$ of area. From this area, the potential landslides cover $13.8 \mathrm{~km}^{2}$, the active landslides cover $0.2 \mathrm{~km}^{2}$ and stabilised landslides cover $8.7 \mathrm{~km}^{2}$. Most potential land- 
slides, almost $9.3 \mathrm{~km}^{2}$ occur on the TAL of arable land, grasslands and pastures of subtype 4a. Likewise, they cover an area of $2.8 \mathrm{~km}^{2}$ on the dispersed settlement of subtype 1a. The stabilised landslides have the greatest extension on the subtype $4 \mathrm{a}$, which represents an area of $5.0 \mathrm{~km}^{2}$ and on the subtype la, they cover an area of $2.1 \mathrm{~km}^{2}$.

The total size of landslides on the areas of TAL within individual cadastres was determined based on the superposition of maps (TAL and landslides). The cadastres were divided into five categories:

1. over 200 ha Oščadnica, Klokočov villages

2. 150-200 ha Skalité, Zákopčie villages

3. 100-150 ha Nová Bystrica, Raková, Vysoká nad Kysucou villages

4. 50-100 ha Čadca, Korňa, Krásno nad Kysucou, Lutiše, Makov, Riečnica, Radôstka, Staškov, Svrčinovec, Zborov nad Bystricou villages

5. up to 50 ha Horelica, Čierne, Dlhá nad Kysucou, Dunajov, Klubina, Harvelka, Olešná I, Olešná II, Podvysoká, Stará Bystrica, Turzovka, Turkov villages.

Localities with the highest percentage of the total area of TAL (Fig. 5) influenced by landslides are in the cadastral areas of Olešná II village and Staškov village (over 40\%). These areas have a low percentage of representation of TAL and also a lower percentage of landslides representation, which means that the majority of TAL areas occur on the landslide territory. In the cadastral area of Olešná II village, the area of TAL after superposition is 23.25 ha, out of which 22.15 ha is influenced by potential landslides ( 8.90 ha of potential landslides are found in the dispersed settlements of subtype $1 \mathrm{~b}$ ). In the cadastral area of Staškov village, the area of TAL that relates to the potential landslides is 32.36 ha (out of the total area of $60.15 \mathrm{ha}$ ). The largest area (22.33 ha) of these landslides is located on the TAL of arable land, grasslands and pastures of subtype 4a. In the cadastral areas of Klokočov, Korňa, Makov, Harvelka, Skalité and Turkov villages, more than 30\% of the total area of TAL is affected by landslides (Fig. 5). In the cadastral area of Turkov village, the potential landslides on the dispersed settlement of subtype la cover an area of 10.66 ha (out of the total area of $35.35 \mathrm{ha}$ ) and in the cadastral area of Harvelka village, the potential landslides on the TAL of arable land, grasslands and pastures of subtype 4a cover an area of 31.07 ha (out of the total area of $37.32 \mathrm{ha}$ ). Potential landslides in the cadastral area of Skalite village cover an area of 171.45 ha (out of the total area of 197.22 ha) of which, an area of 161.11 ha is on the TAL of arable land, grasslands and pastures of subtype 4a. The landslides within cadastral area of Makov village are found on the area of 88.79 ha, out of which, the potential landslides cover an area of 55.65 ha ( 28.89 ha on the subtype $1 \mathrm{la}$ and 26.76 ha on the subtype $4 \mathrm{a}$ ). The highest concentration of landslides within TAL is in the cadastral areas of Zákopčie village and Turkov village where it reaches up to 40.35 and $34.12 \%$, respectively. The potential landslides in Zákopčie village are extended on the area of 70.84 ha of the total area of TAL, out of which, the area of 31.15 ha is on the subtype 1a localities and the area of 27.60 ha on the subtype $4 \mathrm{a}$ localities. $15 \%$ of the Turkov village territory is covered by TAL, out of which, up to $30 \%$ of the area is affected by landslides (10.66 ha of TAL are affected by potential landslides on the subtype 1a).

The occurrence of landslides substantially threatens the localities with TAL of arable land, grasslands and pastures of subtype $4 \mathrm{a}$ (Fig. 6). The active landslides affect an area of 9.18 ha (out of $22.05 \mathrm{ha}$ ) and the potential landslides affect an area of $927.93 \mathrm{ha}$ (out of $1381.63 \mathrm{ha}$ ). In $23 \mathrm{ca}-$ dastral areas (out of 29), the largest coverage of the potential landslides is on TAL. In the localities 


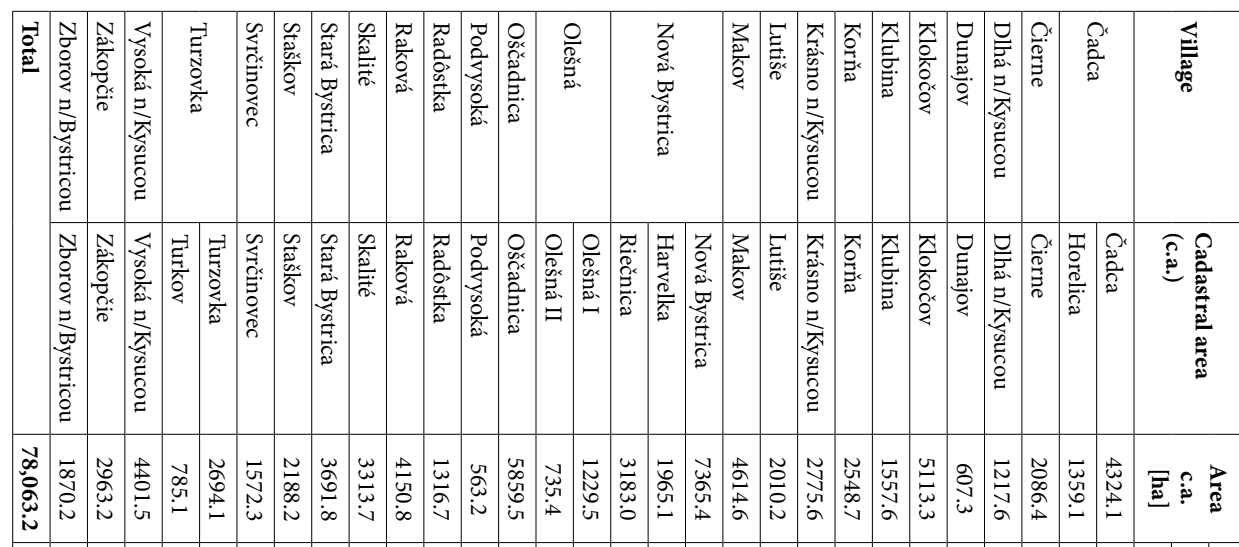

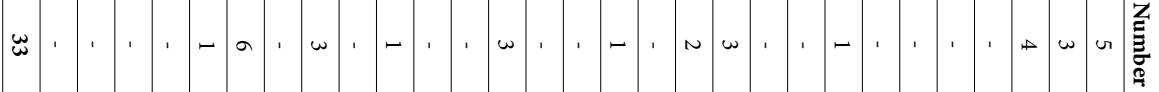

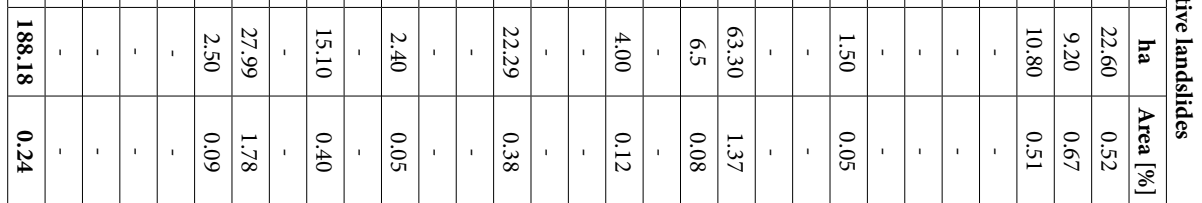

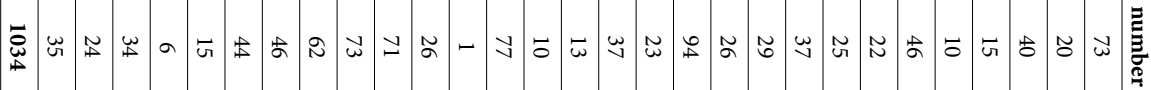

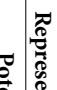

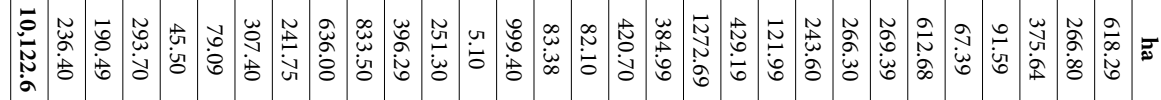

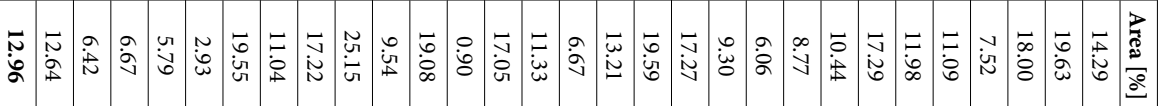
$\stackrel{\circ}{\stackrel{9}{\rightleftarrows}}$

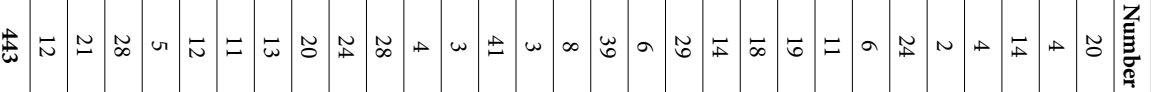

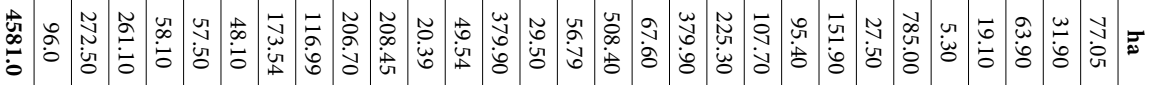

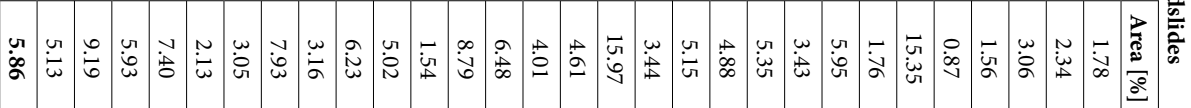

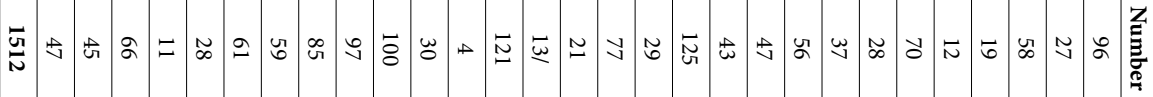

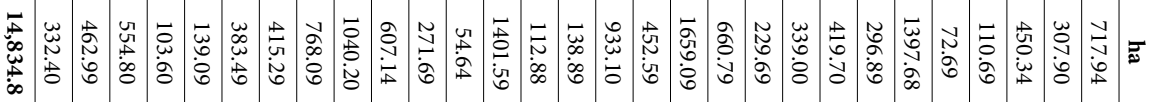

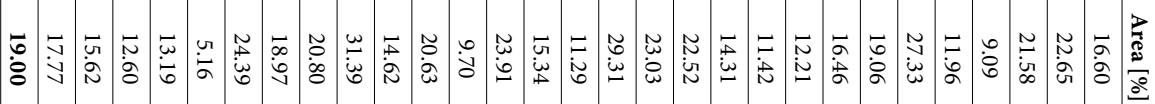




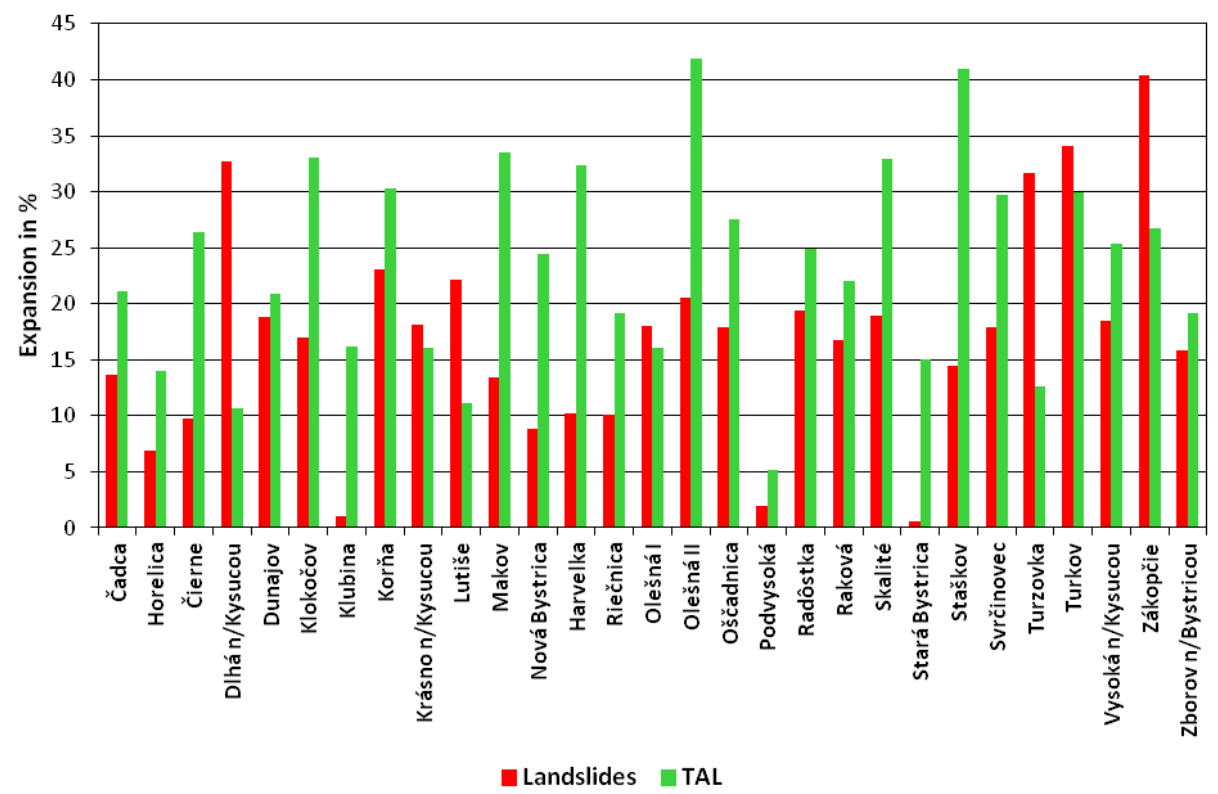

Fig. 5. TAL and landslides concentration in the individual cadastral areas after the superposition.

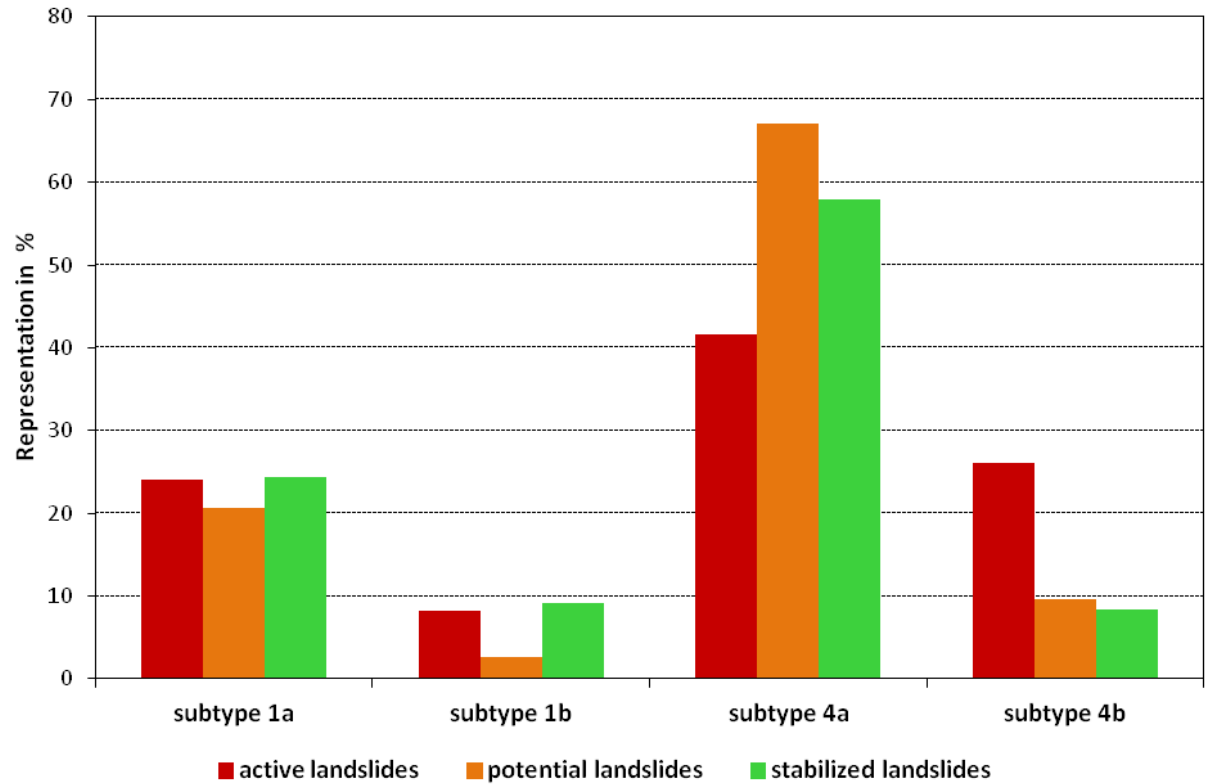

Fig. 6. Landslides representation in the individual types of TAL. 
with dispersed settlements of subtype 1a, the active landslides cover an area of 5.30 ha and the potential landslides cover an area of 284.60 ha.

The active landslides are mostly represented in the TAL of subtype $4 \mathrm{a}$ (cadastral areas of Čadca and Oščadnica villages), of subtype $4 \mathrm{~b}$ (cadastral areas of Riečnica and Svrčinovec villages) and of subtype la (cadastral area of Svrčinovec village). The largest representation of potential landslides is on the subtype $4 \mathrm{a}$, subtype la and subtype $4 \mathrm{~b}$.

\section{Conclusion}

Kysuce territory is characterised by the typical landscape structure characterised by the presence of TAL. TAL formations are connected with the historical presence of human settlements. However, the human activities also caused destruction of a large part of TAL. A large part of these forms of landscape structure was united to large areas of big block fields or recultivated meadows, balks were ploughed and terraces were planed. At present, the preserved forms of TAL face the abandonment of traditional farming methods. Balks and terraces were gradually overgrown by wood species gradually turning into young forest stands.

Natural factors of the natural environment influence a distribution of TAL elements such as forms of anthropogenic relief or anthropogenic landscape. Geological substrate together with slope processes forms the landscape feature and affect the stability of the TAL too. The most widespread geological formations on the Kysuce region are Zlín Formation. In this area, the TAL representing type of dispersed settlements (subtype 1a) cover $40 \%$ of the total area of TAL forms and as a type of typical structures of arable land, grasslands and pastures with typical forms of anthropogenic relief (subtype 4) cover $38 \%$ of the area. For this territory, the localities with a specific type of dispersed settlements (subtype $1 \mathrm{~b}$ ) are characteristic. This subtype binds mainly on deluvial sediments (till $42 \%$ of the TAL) and Godula sequence (12\% of TAL).

From the geomorphological point of view, the whole territory is situated at the Outer Carpathians covering the area of Slovak-Moravian Carpathians, the Western and Central Beskids. Considering the geological substrate, when there is high presence of unstable flysch rocks, it results in a high concentration of active or potential landslides in the area. These landslides influence the existence and stability of TAL forms. In term of landslides, the TAL forms are mostly affected in Olešná and Staškov villages (over $40 \%$ of the TAL). More than $30 \%$ of the TAL area is affected by landslides in Klokočov, Korňa, Makov, Harvelka, Skalité and Turkov villages. Active landslides most threaten typical TAL of arable land, grasslands and pastures (type 4), especially in Čadca town, Oščadnica, Riečnica and Svrčinovec villages.

Mapping of TAL forms and elements and evaluation of TAL threats by slope deformations is part of a large database of monitoring area. These data can serve as valuable sources of information for spatial planning at national, regional and local levels. The data are also available for the purpose of nature and landscape protection and preservation of the historical aspect of the landscape based on the forms of traditional agricultural utilisation of TAL.

\section{Acknowledgements}

The contribution was prepared within the grant project of the Ministry of Education of the Slovak Republic and the Slovak Academy of Sciences No. 2/0078/15 'Ecological optimization of the utilization of landslide areas in selected parts of the flysch zone in regard to the traditional farming. 


\section{References}

Agnoletti, M., Cargnello, G., Gardin, L., Santoro, A., Bazzoffi, P., Sansone, L., Pezza, L. \& Belfiore N. (2011). Traditional landscape and rural development: comparative study in three terraced areas in northern, central and southern Italy to evaluate the efficacy of GAEC standard 4.4 of cross compliance. Italian Journal of Agronomy, 6(1s):e16, 121-139. DOI: 10.4081/ija.2011.6.s1.e16.

Andor, L. (1978). Slope disturbances in the Carpathian flysch (in Slovak). Unpublished graduation thesis. Bratislava: Univerzita Komenského, Prírodovedecká fakulta.

Antrop, M. (2005). Why landscapes of the past are important for the future. Landsc. Urban Plann., 70, 21-34. DOI: 10.1016/j.landurbplan.2003.10.002.

Barančok, P. \& Barančoková M. (2012). Research of landscape diversity of Kysuce region with emphasis on the historical structure of the agricultural landscape (in Slovak). Životné Prostredie, 46, 11-15.

Cullotta, S. \& Barbera G. (2011). Mapping traditional cultural landscapes in the Mediterranean area using a combined multidisciplinary approach: Method and application to Mount Etna (Sicily; Italy). Landsc. Urban Plann., 100, 98-108. DOI: 10.1016/j.landurbplan.2010.11.012.

Gerard, F., Petit, S., Smith, G., Thomson, A., Brown, N., Manchester, S., Wadsworth, R., Buga r, G., Halada, L., Bezák, P., Boltiziar, M., De Badts, E., Halabuk, A., Mojses, M., Petrovic, F., Gregor, M., Hazeu, G., Mücher, C.A., Wac howicz, M., Huitu, H., Tuominen, S., Köhler, R., Olschofsky, K., Ziese, H., Kolar, J., Sustera, J., Luque, S., Pino, J., Pons, X., Roda, F., Roscher, M. \& Feranec J. (2010). Land cover change in Europe between 1950 and 2000 determined employing aerial photography. Progress in Physical Geography, 34, 183-205. DOI: $10.1177 / 0309133309360141$

Harrop, S.R. (2007). Traditional agricultural landscapes as protected areas in international law and policy. Agric. Ecosyst. Environ., 121(3), 296-307.

Haško, J. \& Polák M. (1979a). Geological map of the Kysucké vrchy Mts and Krivánska Malá Fatra Mts (in Slovak) 1:50 000. Bratislava: GÚDŠ.

Haško, J. \& Polák M. (1979b). Notes to the geological map of the Kysucké vrchy Mts and Krivánska Malá Fatra Mts (in Slovak). Bratislava: GÚDŠ.

Lapin, M., Faško, P., Melo, M., Štastný, P. \& Tomlain J. (2002). Climatic regions (in Slovak). In Atlas krajiny SR (pp. 95). Bratislava: MŽP SR, Banská Bystrica: SAŽP.

Marini, L., Klimek, S. \& Battisti, A. (2011). Mitigating the impacts of the decline of traditional farming on mountain landscapes and biodiversity: a case study in the European Alps. Environmental Science \& Policy, 14(3), $258-267$. DOI: $10.1016 /$ j.envsci.2010.12.003.

Mazúr, E. \& Lukniš M. (1986). Geomorphological division of SSR and ČSSR. Part Slovakia (in Slovak). Bratislava: Slovenská kartografia.

Miklós, L. (2002). Natural - settlement nodal regions (in Slovak). In Atlas krajiny SR (pp. 206-207). Bratislava: MŽP SR, Banská Bystrica: SAŽP.

Olah, B., Boltižiar, M. \& Gallay I. (2009). Transformation of the slovak cultural landscape since the 18th cent. and its recent trends. Journal of Landscape Ecology, 2(2), 41-55.

Ondrášik, R. \& Rybář J. (1991). Dynamic engineering geology (in Slovak). Bratislava: SPN.

Palang, H. (2010). Time boundaries and landscape change: collective farms 1947-1994. European Countryside, 2, 169-181. DOI: 10.2478/v10091-010-0012-6.

Plieninger, T., Höchtl, F. \& Spek T. (2006). Traditional land-use and nature conservation in European rural landscapes. Environmental Science \& Policy, 9, 317-321. DOI: 10.1016/j.envsci.2006.03.001.

Potfaj, M., Maglay, J., Šlepecký, T. \& Teták F. (2002). Geological map of the Kysuce region 1:50 000 (in Slovak). Bratislava: ŠGÚDŠ.

Potfaj, M. (Ed.) (2003a). Notes to the geological map of the Kysuce region (in Slovak). Bratislava: ŠGÚDŠ.

Potfaj, M., Šlepecká, T., Beleš, F., Sandanus, M., Vondráček, L., Hanzel, V., Jezný M., Kandera, K., Čurlík, J., Šefčík, P., Martinčeková, T. \& Januš J. (2003b). Set of regional maps of geological environmental factors River basins Kysuca in scale 1:50000 (in Slovak). Geofond. Bratislava: MŽP SR.

Soták, Š., Liová, S. \& Borsányi P. (2002). Expression of climate variability on the hydrological regime of streams in the Kysuce region (in Slovak). In XIV. Česko-slovenská bioklimatologická konference, 2-4 October 2002 (pp. 389-400). Lednice na Moravě.

Starinský, O. (2004). Evaluation of slope deformations in the Svrčinovec village - part Praženková (in Slovak). Unpublished diploma thesis. Bratislava: Univerzika Komenského, Prírodovedecká fakulta. 
Swinnen, J.F. (1999). The political economy of land reform choices in Central and Eastern Europe. Economics of Transition, 7, 637-664. DOI: 10.1111/1468-0351.00029.

Šimeková, J. \& Martinčeková, T. et al. (2006). Atlas maps of slope stability of the Slovak Republic (in Slovak) M 1:50000. Záverečná správa. Bratislava: MŽP SR.

Špulerová, J., Dobrovodská, M., Lieskovský, J., Bača, A., Halabuk, A., Kohút, F., Mojses, M., Kenderessy, P., Piscová, V., Barančok, P., Gerhátová, K., Krajčí, J. \& Boltižiar M. (2011). Inventory and classification of historical structures of the agricultural landscape in Slovakia. Ekológia (Bratislava), 30(2), 157-170. DOI: 10.4149/ ekol_2011_02_157.

Špulerová, J., Dobrovodská, M., Štefunková, D., Bača, A. \& Lieskovský J. (2014a). Biodiversity of traditional agricultural landscapes in Slovakia and their threats. In S.-K. Hong, J. Bogaert \& Q. Min (Eds.), Biocultural landscapes: Diversity, functions and values (pp. 113-128). Dordrecht: Springer. DOI: 10.1007/978-94-017-8941-7_9.

Špulerová, J., Dobrovodská, M., Štefunková, D., Piscová, V. \& Petrovič F. (2014b). Evolution of the traditional agricultural landscapes of Slovakia. In R. Efe \& M. Ozturk (Eds.), Environment and ecology in the Mediterranean region II (pp. 133-145). Newcastle: Cambridge Scholars Publishing.

Tempesta, T. (2010). The perception of agrarian historical landscapes: A study of the Veneto plain in Italy. Landsc. Urban Plann., 97, 258-272. DOI: 10.1016/j.landurbplan.2010.06.010.

Tóthová Z., Sabo P. \& Čárska H. (Eds.), (Bevilaqua D., Čárska H., Darnady A., Derka T., Galvánek J., Gerát R., Hudek V., Korňan J., Kuderavá Z., Matejová M., Pietorová E., Sabo P., Šulgan M., Tóthová Z., Urbanová V., Vrábel J.) (1996). Kysuce region nature protection and cooperation on the sustainable development (in Slovak). Published by the IUCN Foundation, World Union of Nature Protection, Slovakia, Bratislava, Cambridge, United Kingdom and Gland, Switzerland.

Žabková, E., Grenčíková, A., Vrábel, P., Sluka, V., Frličková, M., Molčan, T., Lenková, M., Buček, L. \& Flimmel J. (2003). Kysuca river basic - slope deformation (in Slovak). Geofond. Bratislava: MŽP SR. 